\title{
A Basic Study on the Analysis of Spatial Structure by Horizontal Expansion of Museums
}

\author{
Kyungmo Koo ${ }^{1}$, Youhee $\mathrm{Heo}^{2}$ and Heangwoo Lee $^{3 *}$ \\ ${ }^{1}$ Department of Interior Design, College of Design, Sangmyung University, Korea \\ ${ }^{2,3}$ Major of Space Design, College of Design, Sangmyung University, Cheonan, Korea \\ 1ong2km@gmail.com, ${ }^{2}$ youhee0409@naver.com, ${ }^{3} 2 \mathrm{hw} @ s m u . a c . k r$
}

\begin{abstract}
In recent years there has been a growing demand for museums due to an increase in cultural interest among visitors, and extensions are being carried out more frequently for older museums built due to an increase in the number of collections. However, not enough precedent studies regarding the extension of a museum have been carried out. Therefore, the purpose of this study is to establish preliminary data that will assist in constructing a museum in the future by analyzing the change in space composition, targeting actual museums that have been extended recently. The result of this study is as follows. The ratio of exhibition space, storage space, and common use space among the space composition ratio of museums that have been extended recently is increasing. Notably, the ratio occupied by experiential space is higher after extension, indicating that experiential space has become more important. The length of the visitor circulation path was also affected due to the increase of the area before and after the museum extension. However, an increase in the length of the visitor circulation path may result in a drop in the visitors' concentration, and a rest area has become more important as an approach to addressing such issue. This study has significance as a basic study on the spatial analysis before and after the museum extension. However, this study has the limitation of not reflecting the visitors' psychology in the analysis method, and future research should address this.
\end{abstract}

Keywords: Museum, Horizontal expansion, Space composition, Area, Visitor's movement line

\section{Introduction}

The number of collections in a museum increases with the passage of time, and the extension of exhibition and storage spaces is required as a result [1][2][3]. In addition, beyond its function of preserving relics of the past, the museum is a space for social communication, and its functions are being diversified and subdivided [4][5]. Therefore, extension is essential for a museum, and spaces with a new function that were not available in museums of the past are introduced in the extension process. Regardless of such demand for museum extension and considerations, there have not been sufficient studies considering such aspects.

As such, the purpose of this study is to establish preliminary data for the extension of a museum which will be actually carried out in the future by analyzing the change in the space composition before and after the extension, targeting actual museum extension cases.

Article history:

Received (May 12, 2020), Review Result (June 19, 2020), Accepted (July 21, 2020) 


\section{Consideration of concept of museum and its extension}

\subsection{Definition and role of museum}

In the International Council of Museums (ICOM) Statutes, a museum is defined as "a nonprofit, permanent institution in the service of society and its development, open to the public, which acquires, conserves, researches, communicates and exhibits the tangible and intangible heritage of humanity and its environment for the purposes of education, study and enjoyment." The initial roles of such museum have been considered as preserving relics of the past, and the education and experience of the general public. However, the functions of the museum are being subdivided into the role of preserving relics of the past, the role of education and experience of visitors, and the role of communication. In this regard, it is considered that the necessity of the museum will be further emphasized and the demand for museum extension will further increase in order to respond to such demand. But as shown in [Table 1], no study regarding museums in consideration of extension has been carried out, indicating the need for the current study.

Table 1. Precedent studies related to the museum

\begin{tabular}{|c|c|c|c|}
\hline Title of study (paper) & $\begin{array}{c}\text { Year of } \\
\text { publication }\end{array}$ & Purpose of study (paper) & $\begin{array}{c}\text { Consideration } \\
\text { of museum } \\
\text { extension }\end{array}$ \\
\hline $\begin{array}{c}\text { Study on Using Space } \\
\text { Design for Temporary } \\
\text { Exhibition at Museum [6] }\end{array}$ & 2012 & $\begin{array}{c}\text { The purpose of this study is to review the } \\
\text { measures to use space design for temporary } \\
\text { exhibitions at museums, and present } \\
\text { preliminary data for temporary exhibition. }\end{array}$ & $\times$ \\
\hline $\begin{array}{c}\text { A Study on the Complex } \\
\text { Cultural Space in Museum } \\
\text { [7] }\end{array}$ & 2015 & $\begin{array}{c}\text { This study presented the direction for a } \\
\text { complex museum by proposing measures for } \\
\text { each function, content, and space through the } \\
\text { complexation. }\end{array}$ & $\times$ \\
\hline $\begin{array}{c}\text { An Analysis of Museum } \\
\text { Exhibition Space using } \\
\text { Space Syntax Theory [8] }\end{array}$ & 2019 & $\begin{array}{c}\text { This study presented basic museum design } \\
\text { data by quantitatively analyzing the spaces in } \\
\text { the museum and comparing and analyzing } \\
\text { quantitative data. }\end{array}$ & $\times$ \\
\hline
\end{tabular}

\subsection{Concept and types of extension}

Extension refers to expanding the floor area of a building in the same space in the form of adding a new space to an existing building; construction of an additional (annex) building is also called extension. As shown in [Table 2], extensions can be classified into vertical extension, horizontal extension, separation type extension, construction of a separate building, and customized extension. Vertical extension is the method of constructing an additional number of floors on top of an existing building. This method is used to reduce costs or when horizontal extension is unavailable. Horizontal extension is the method of widening the front and the rear of an existing building. This method can widen the actual floor area, but has higher financial costs. The separation type extension is the method of widening the area of an existing building sideward separately. This method can separate the area extended through horizontal extension, etc., and the owner can generate lease income from each separated area. The construction of a separate building is the method of constructing a new building in addition to an existing building, which can also be called an annex building, and this is the safest method since this method does not extend an existing building. Customized extension is the method of repairing and replacing old interior materials or bathrooms without widening 
the floor area of an existing building, and is the most inexpensive method. This study only targeted horizontal extension, the most common method. [9]

Table 2. Types of extension

\begin{tabular}{|c|c|c|c|c|c|}
\hline $\begin{array}{c}\text { Types of } \\
\text { extension }\end{array}$ & $\begin{array}{c}\text { Virtical } \\
\text { extension }\end{array}$ & $\begin{array}{c}\text { Horizontal } \\
\text { extension }\end{array}$ & $\begin{array}{c}\text { Segregated } \\
\text { extension }\end{array}$ & $\begin{array}{c}\text { Detached } \\
\text { extension }\end{array}$ & $\begin{array}{c}\text { Customized } \\
\text { extension }\end{array}$ \\
\hline $\begin{array}{c}\text { Image of } \\
\text { extension }\end{array}$ & & & & & \\
\hline
\end{tabular}

\subsection{Consideration of visitor circulation paths in a museum}

The circulation path of a visitor in a museum is an important element in planning the museum, as it affects the knowledge the visitor obtains from the museum, as well as the visitor's concentration. There are three types of visitor circulation path: arbitrary circulation path, suggested circulation path, and guided circulation path. The arbitrary circulation path is selected by a visitor who goes to the museum without a guide. In the suggested circulation path, the circulation of visitors is guided by media, without the installation of any obstacle that hinders the circulation path in the exhibition center. In the guided circulation path, visitor choice is eliminated, and visitors circulate in the direction guided by spaces or exhibits. There is also a method of classifying the circulation paths according to the number of entrances in the museum. The first method is the dispersed circulation path system, and the second is the concentrated circulation path system. There are two or more entrances and exits in the dispersed circulation path system, so visitors do not need to follow a certain circulation path guided in the exhibition center. The visitors can freely circulate or watch exhibits using their own way in the exhibition center, but there is a difficulty in understanding or watching many exhibits at once, so they need to visit the museum a number of times. In the concentrated circulation path system, the administrator can control and monitor the visitor circulation, and visitors can receive information regarding systematically prearranged circulation paths according to the circulation guide system. However, visitors cannot select their circulation path freely, and may receive a stronger impression from exhibits they view earlier.

\section{Analysis of space composition according to the museum extension}

\subsection{Setting of the analysis target}

It was determined that a museum that had undergone a large change in the extension area would be an appropriate target for this study. It was also considered necessary to select a museum that opened prior to 2000, which was the period of modernization; furthermore, a national museum would provide the best data given its public nature. Accordingly, Iksan museum was set as the analysis target, as shown in [Table 3]. Iksan museum efficiently preserves and exhibits cultural heritages excavated from the Mireuksa Temple Site, which was designated as a World Natural Heritage site by UNESCO. Iksan museum works to achieve systematic management in order to become a representative multiplex cultural space of Iksan in the future. The space composition and the floor plan of Iksan museum after its extension are as shown in Figure 1 and displayed in diagram form as follows. 




Figure 1. Iksan Museum floor plan visitor circulation path

Table 3. Outline of analysis target

\begin{tabular}{|c|c|c|c|c|c|c|}
\hline \multirow{2}{*}{$\begin{array}{l}\text { Name of } \\
\text { museum }\end{array}$} & \multirow{2}{*}{$\begin{array}{c}\text { Exhibition } \\
\text { subject }\end{array}$} & \multirow{2}{*}{$\begin{array}{c}\text { Opening } \\
\text { period }\end{array}$} & \multirow{2}{*}{$\begin{array}{c}\text { Extension } \\
\text { period }\end{array}$} & \multirow{2}{*}{ Type of extension } & \multicolumn{2}{|c|}{$\begin{array}{l}\text { Building floor } \\
\text { area }\left(\mathrm{m}^{2}\right)\end{array}$} \\
\hline & & & & & $\begin{array}{l}\text { Before } \\
\text { extension }\end{array}$ & $\begin{array}{c}\text { After } \\
\text { extension }\end{array}$ \\
\hline Iksan Museum & Relic & 1994.10 & 2020.01 & Horizontal extension & 2,972 & 7,499 \\
\hline
\end{tabular}

\subsection{Analysis method}

In this study, the effect of a change in the floor plan of the museum is analyzed by investigating the change before and after the museum extension. The findings of this analysis are as follows. First, the change in the building area before and after the museum extension and the extension method were determined. Second, the change in the ratio of exhibition space, storage space, business space, and common use space among various spaces composing the museum was also analyzed according to the analysis of the change in the area before and after the museum extension. In addition, the effect according to the ratio of experience space was analyzed by drawing the ratio of experience space. Third, the necessity of increasing the ratio of common use space was analyzed by drawing the rate of increase in the length of the visitor circulation path according to the ratio of increase in the area before and after the museum extension.

\subsection{Analysis result and discussion}

This study is a basic study analyzing the change in spatial composition before and after a museum extension, and the results are as shown below.

First, the rate of increase in total building floor area before and after the extension of Iksan museum, the museum selected for this study, was $152.3 \%$, as shown in [Table 3]. This was the result of various factors, including an increase in the number of visitors, themes and collections of the museum.

Second, the ratio occupied by each space in the museum before and after the museum extension is as shown in [Figure 2], and the ratio of exhibition space, storage space, and common use space has increased in comparison to the ratio of other spaces. On the other hand, 
the ratio of business space and other spaces has decreased. Next, the space in a modern museum that is considered important can be derived by examining the change in the spaces before and after the museum extension. In addition, the importance of experiential spaces that lead the visitors' participation in the exhibition space is emphasized through such change. With the extension, experiential elements are emphasized, in contrast to past spaces that simply emphasized the exhibition. This shift is confirmed by the fact that the ratio of experiential space has increased by $9.5 \%$, while the ratio of the exhibition area increased by just $6.5 \%$. The area of business space in the museum did not increase, but the whole building area increased due to the extension, decreasing its ratio. The ratio of common use space has increased by $4.2 \%$, indicating that the museum has become a multiplex cultural space as shown in [Figure 2].

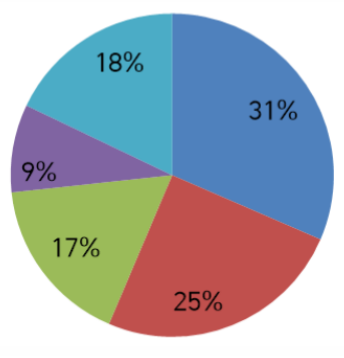

Before

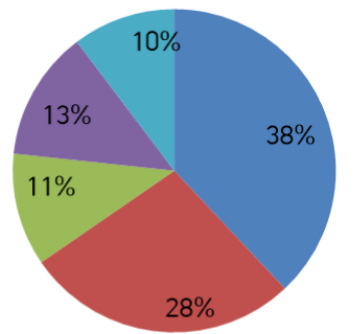

After
Exhition Space

- Museum Storage

- Work Space

- Communal Space

Etc

Figure 2. Ratio of space composition before and after the museum extension

Third, the length of the visitor circulation path has increased by $146.8 \%$ due to the museum extension, from $160 \mathrm{~m}$ to $395 \mathrm{~m}$. The length of the visitor circulation path has increased as the area increased by $152.3 \%$ before and after the museum extension. However, the rate of increase in the length of the visitor circulation path is slightly lower in comparison to the rate of increase in the area before and after the museum extension. Therefore, it is necessary to determine the actual visitor circulation path and establish an efficient visitor circulation path.

\section{Conclusion}

This study was a basic study regarding the change in the spatial composition before and after the museum extension, and the extension method and changes in the space composition ratio, area, and circulation paths were analyzed by examining the Iksan museum, which was recently extended. The conclusion of this study is as follows.

The museum extension increases the area generally, but the increase or decrease in the ratio of each space varies. Among those spaces, the ratio of exhibition space, storage space and common use space shows an increase in comparison to the ratio of other spaces. In particular, the ratio of experiential space in the exhibition space before and after the extension has increased, indicating the importance of experience-based activities among the museum programs. The ratio of common use space in the museum has also increased, reflecting the needs of visitors who want to take a rest and use convenient facilities in the course of moving through a long circulation path. On the other hand, the ratio of business space and other spaces has been maintained, but decreases when the extension is carried out and the whole building area increases. This indicates that business space and other spaces have become less 
important. After the museum extension, the length ratio of the visitor circulation path increased as the ratio of exhibition space increased, and the circulation time also increased accordingly, resulting in an increase in the area of common use space for taking a rest. However, the rate of increase in the number of visitors is lower than the rate of increase in the area before and after the museum extension. Therefore, it is necessary to determine the actual visitor circulation path and establish an efficient visitor circulation path. This study has significance in that its findings can be utilized as data for museum extensions in the future. However, the focus was placed on changes in space composition before and after the museum extension, so details including the visitors' psychology could not be reflected. As such, an advanced study reflecting subsequent visitors' position should be carried out in the future.

\section{References}

[1] S. W. Jeong and C. J. Lim, "A study on the environment planning of overseas museum storage," Journal of Architectural Institute of Korea, vol.18, no.2, pp.11-21, (2008)

[2] S. W. Jeong, "Classification system of collections and distribution of storages in domestic museum of historic relics," Journal of Korean Institute of Interior Design, vol.15, no.2, pp.138-150, (2006)

[3] D. G. Cui and S. K. Kong, "A study on analysis of functional area programs and space composition of the architecture \& urbanism museum," Journal of the Korea Institute of Spatial Design, vol.12, no.5, pp.253-263, (2017)

[4] H. R. K and J. A. Choi, "A study of stair-shaped open space design tendencies as a reinforcement element of museum publicity," Journal of the Korea Institute of Spatial Design, vol.14, no.6, pp.241-257, (2019) DOI:10.35216/kisd.2019.14.6.241

[5] Y. S. Kim, "A study on the spatial organization of exhibition spaces in museums," Journal of the Architectural Institute of Korea, vol.11, no.11, pp.78-89, (1995)

[6] S. W. Jeong, "A study on the relationship between the spatial configuration and visitor's movement in museum," Journal of the Architectureal Institute of Korea Planning \& Design, vol.22, no.10, pp.167-175, (2006)

[7] D. H. Kim, "A study on the complex cultural space in museum," Journal of International Association for Glocal Culture, vol.2, no.3, pp.1-22, (2015)

[8] Y. R. Kim and J. W. Chae, "An analysis of museum exhibition space using space syntax theory," Journal of the Korea Institute of Spatial Design, vol.14, no.2, pp.81-91, (2019)

[9] J. J. Kim and D.N. Choi "Study on urban contemporary museum extension", Architectural Institute of Korea, vol.32, no.2, pp109-110, (2012) 